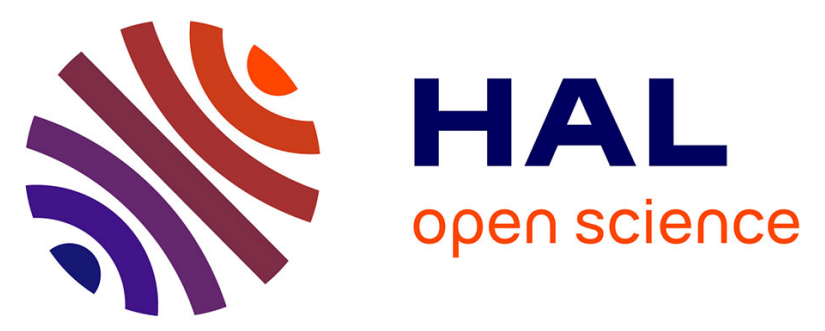

\title{
Hooks equipped with magnets can increase catches of blue shark (Prionace glauca) by longline fishery
}

Sebastián Biton Porsmoguer, Daniela Bănaru, Charles F. Boudouresque, Ivan

Dekeyser, Christophe Almarcha

\section{- To cite this version:}

Sebastián Biton Porsmoguer, Daniela Bănaru, Charles F. Boudouresque, Ivan Dekeyser, Christophe Almarcha. Hooks equipped with magnets can increase catches of blue shark (Prionace glauca) by longline fishery. Fisheries Research, 2015, 172, pp.345-351. 10.1016/j.fishres.2015.07.016 . hal03566806

\section{HAL Id: hal-03566806 https://hal.science/hal-03566806}

Submitted on 3 Mar 2022

HAL is a multi-disciplinary open access archive for the deposit and dissemination of scientific research documents, whether they are published or not. The documents may come from teaching and research institutions in France or abroad, or from public or private research centers.
L'archive ouverte pluridisciplinaire HAL, est destinée au dépôt et à la diffusion de documents scientifiques de niveau recherche, publiés ou non, émanant des établissements d'enseignement et de recherche français ou étrangers, des laboratoires publics ou privés. 


\section{Hooks equipped with magnets increase catch of blue shark (Prionace glauca) by longline fishery}

Sebastián Biton Porsmoguer ${ }^{a^{*}}$, Daniela Bănaru ${ }^{\mathrm{a}}$, Charles F. Boudouresque ${ }^{\mathrm{a},}$ Ivan Dekeyser $^{\mathrm{a}}$ and Christophe Almarcha ${ }^{\mathrm{b}}$

${ }^{a}$ Aix-Marseille University, CNRS, Toulon University, IRD, MIO (Mediterranean Institute of Oceanography) UM110, Campus de Luminy, Case 901, 13288 Marseille cedex 09, France.

b Aix-Marseille University, CNRS, Centrale Marseille, IRPHE, UMR 7342, 13384 Marseille, France

* Corresponding author: sebastien.biton@mio.osupytheas.fr

\section{Short title. Magnets do not reduce by-catch of blue shark}

\section{Abstract}

The blue shark (Prionace glauca) populations are decreasing wordwide and the species is currently classified as near threatened. However it is the main species caught by the Spanish and Portuguese longline fisheries; and blue shark is specifically targeted by a part of these fleets in the northeastern Atlantic Ocean. Sharks are well known to be able to detect electric fields in the microvolt range and this sense has been proposed to provide a mechanism to detect the earth's magnetic field. As a result, the use of magnets has been proposed as a measure to reduce shark interaction with fishing gear. We therefore tested two models of high field strength neodymium magnets to effect shark catch rates during commercial longline fishing operations. Our results show that magnets do not reduce blue shark catch rates and can even have an attractive effect. This effect was significantly higher for the larger magnet model tested $(26 \mathrm{~mm} \times 11 \mathrm{~mm} \times 12 \mathrm{~mm}$, $0,885 \mathrm{~T}$ ) compared to the smaller one (20 $\mathrm{mm} \times 13 \mathrm{~mm} \times 15 \mathrm{~mm}, 0,464 \mathrm{~T})$. We also noted that hooks remain magnetized after removal of the magnets and are even slightly magnetized without any previous contact with a magnet. 


\section{Keywords}

Blue shark, by-catch, longline, magnet, repellent, CPUE

\section{Introduction}

The blue shark Prionace glauca (Linnaeus, 1758) is a species with worldwide distribution (Moreno, 2004). Like most of pelagic shark species, the blue shark presents a low fecondity rate and a slow growth rate (Ferretti et al., 2008) and is therefore particularly vulnerable to fishery exploitation.

In the northeastern Atlantic Ocean, one part of the Spanish and Portuguese longline fleet targets swordfish Xiphias gladius Linnaeus, 1758, tuna (teleosts of the group Thunini) and shortfin mako near Azores archipelago and between Azores archipelago and Iberian Peninsula (Buencuerpo et al., 1998; Stevens et al., 2000; Baum and Myers, 2004). The bait is mackerel (Scomber scombrus). However, about $60 \%$ of the catch is represented by blue shark (Xunta de Galica. pers. comm.). The second part of the longline fleet concerned by this study targets only blue shark (Prionace glauca) near Iberian Peninsula. The bait is longfin inshore squid (Doryteuthis pealeii). Over 200 tons of blue shark were landed each month in 2013 in Vigo (Xunta da Galicia, i.e. regional government, pers. comm.). In both case, Spanish and Portuguese longline fishermen can be interested by a repulsive system as if they catch more commercial species like swordfish and tuna they may increase their profit. Moreover most pelagic sharks are on top of the food web and play an important role in marine ecosystems as they contribute to the management of healthy ocean ecosystems (Ferretti et al., 2010).

Elasmobranchs use the electric sense due to the ampullae of Lorenzini for the detection of the bioelectric fields produced by prey organisms (Kalmijn, 1971). However the chemoreception will be probably used on large distances to detect prey even if at a small distance from the prey electric sense may influence their behaviour. According to Hueter et al. (2004) Prionace glauca is attracted to an area by odor but preferentially attacked an active dipole source that simulated the prey's bioelectric field rather than the odor source of the prey. This electric sense is also related to their two modes of navigation. In the passive mode, the elasmobranch simply measures the electric fields are produced by the flow of ocean water through the Earth's magnetic field. In the active mode, the elasmobranch measures the voltage gradients that are induced through 
66

67

68

the animal's body due to its own swimming movements through the geomagnetic field (Hueter et al., 2004).

Permanent magnets have been shown to have repellent effect on sharks by creating an abnormally strong electrical stimulus to overwhelm the elasmobranchs' acute electrosensory system (Stoner et al., 2008; Tallack and Mandelman, 2009; O'Connell et al., 2011a, 2012; Hutchison et al., 2012). Magnets constitute therefore a possible means to reduce the by-catch. Actually, among 20 pelagic shark species concerned by fisheries and/or bycatch, three are now classified by the International Union for the Conservation of Nature (IUCN, 2013) as endangered, namely Mobula mobular (Bonnaterre, 1788), Sphyrna lewini Griffith \& Smith, 1834, Sphyrna mokarran Rüppell, 1837, nine as vulnerable, namely Alopias pelagicus Nakamura, 1935, A. superciliosus Lowe, 1841, A. vulpinus (Bonnaterre, 1788), Carcharodon carcharias (Linnaeus, 1758), Cetorhinus maximus (Gunnerus, 1765), Isurus oxyrinchus Rafinesque, 1810, I. paucus Guitart, 1966, Lamna nasus (Bonnaterre, 1788), Sphyrna zygaena (Linnaeus, 1758), and one, $P$. glauca, as near threatened.

During the last years, many works tried to test the deterrent electromagnetic effect on sharks (Annexe 1). They used permanent magnet composed by Barium (Ba), Boron (B), Iron $(\mathrm{Fe})$ and Neodymium $(\mathrm{Nd})$ or electropositive metal (EPM) composed by Lanthanides metal. Different EPM tested were Barium (Ba), Neodymium (Nd), Praseodymium (Pr), Cerium (Ce), Cerium-Lanthanum (CeLa), PraseodymiumNeodymium metal alloy (PrNdA), and Praseodymium-Neodymium mischmetal (PrNdM) (Annexe 1).

The tests published were realized in laboratory (in experimental conditions) or in field (in experimental conditions, in experimental fishing or in real fishing conditions). Many species were used to test several magnet models or EPM. Some species have a pelagic behaviour (Dasyatidae, Carcharhinidae, Lamnidae, Sphyrnidae and Triakidae) and others, a benthic behaviour (Rajidae and Squalidae). The results show contrasted effects. In laboratory, the results of experiments are sometimes positive (Brill et al., 2009; Rigg et al., 2009; O'Connell et al., 2010; Jordan et al., 2011; O'Connell et al., 2011b, 2014a, 2014c; Smith and O'Connell, 2014), and sometime, negative or partial (Stoner and Kaimmer, 2008; Rigg et al., 2009; Jordan et al., 2011; McCutcheon and Kajiura, 2013). Tests realized in field obtained both positive (Rice, 2008; Wang et al., 2008; O'Connell et al., 2011a, 2014b, 2014d, 2015) and negative results (Robbins et al., 
2008; Tallack and Mandelman, 2009; O'Connell et al., 2011a; Hutchinson et al., 2012; Godin Cosandey et al., 2013; Smith, 2013; O'Connell et al., 2014d).

Some species may have opposite behaviour in different conditions. For example, smooth dogfish (Mustelus canis) in contact with Neodymium (Nd) metal can have a repellent reaction in group but not alone (Jordan et al., 2011). Carcharhinus plumbeus can have a repellent reaction in laboratory (Brill et al., 2009) but not in field (O'Connell et al., 2011a). Globally, all the tests with electromagnetic dispositive obtained highly contrasted results between laboratory and field experiments, between species and according to the electromagnetic dispositive.

Repellent effects with EPM were proposed to be used to limit the intense fishing activities especially for blue shark (Prionace glauca) and shortfin mako (Isurus oxyrinchus). However, previous experiments realized in field and in real fishing conditions with EPM, were negative for both species (Hutchinson et al., 2012; Godin Cosandey et al., 2013).

The aim of this paper was to test the effects of neodymium magnets on catches of the blue shark aboard a fishing vessel targeting pelagic species in the eastern Atlantic Ocean. This is the first paper measuring and taking into account the physical properties of the magnets and their effect on the hooks.

\section{Methods}

\section{Physical properties of the two magnet models}

The magnet is mainly composed of neodymium, a magnet element with high resistance in time and magnet power. The magnets were of the N35-Ni and N35-NdFeB types. The higher the grade (the number following the ' $\mathrm{N}$ '), the stronger the magnet. $\mathrm{Ni}$ indicates the presence of traces of nickel. $\mathrm{NdFeB}$ indicates that the magnet is composed of neodymium, iron and boron. Neodymium is a rare-earth magnet element with degradation trends in sea water. However the experiment lasted only 3 days and there was no degradation of the magnets. We did not measure the level of dissolution in laboratory because as the lanthanides dissolve, the voltage $(\mathrm{mV})$ remains unchanged despite the decreasing mass (McKutcheaon and Kajiura, 2013). The dimensions of the two cylindrical magnet models with a central hole, tested were $26 \mathrm{~mm}$ x $11 \mathrm{~mm}$ x $12 \mathrm{~mm}$ (model 1, 0,885 tesla - from Ingeniera Magnética Aplicada, 
132

133

134

135

136

137

138

139

140

141

142

143

144

145

146

147

148

149

150

151

152

153

154

155

156

157

158

159

160

161

162

163

Barcelona, Spain) and $20 \mathrm{~mm}$ x $13 \mathrm{~mm}$ x $15 \mathrm{~mm}$ (model 2, 0,464 tesla - from Firstmagnetic, Roncq, France). The magnetic fields produced by the two types of magnets, with the hook, were measured at several distances (between 7 and $70 \mathrm{~cm}$ ). We also measured the magnetic fields of two hooks after contact with the two types of magnets and the magnetic fields of a hook which was never in contact with magnets. As each model has always been composed of three magnets in experiments, we report here the measurements for sets of three magnets. When magnets are stuck together, the magnetic field produced by three magnets is not exactly equal to three times the field produced by one as they are not physically at the same point (the more distant magnet has a lower influence, due to the increasing discrepancy of magnetic field with distance). But at a long distance in relation to the size of the magnet, the field can be considered as approximately three times the field of each.

The hook used in the experiments is made of steel, a ferromagnetic material. In consequence, it concentrates the magnetic lines and changes the map of the magnetic field. Moreover, the size of the hook is much larger than the size of the magnets so that very close to the hook, if the magnets are on the opposite side of the hook, the magnetic field can be greater than what it would be with the magnets alone. To measure precisely the field produced, we used a Gauss/Teslamètre Sypris 7030 F.W.Bell and recorded the variation in the magnetic field in a figure that gives the magnetic field in tesla units along the distance $\mathrm{X}$ in centimeters for a hook filled with respectively big magnet (big circle) and small magnet (small circle) in a log-log scale. The measurements were made from the position of the center of the magnet on the hook (approximate position when magnet was absent). The magnetic fields of two hooks after contact with the two types of magnets and the magnetic fields of a hook which was never in contact with magnets were also recorded in the same figure.

\section{Experiments under real fishing conditions}

The experiments were carried out in the northeastern Atlantic Ocean $\left(8^{\circ}-9^{\circ} \mathrm{W}\right.$ and $42^{\circ}$ $-45^{\circ} \mathrm{N}$ ) (Figure 1) aboard a longline fishing vessel, during 3 days (October 2013). The vessel, the Pescalema, was based in Muxía, a small port in Galicia (Spain). The vessel, $\sim 20 \mathrm{~m}$ long, carried 8 crew members, plus the scientific observer (SBP). The experiments concerned 1076 shark individuals. We determined their sex and 
approximate size. They belonged to the following size classes (cm): [90-100), [100110), [110-120), [120-130), [130-140), [140-150), [150-200), [>200.

The longline measured about $50 \mathrm{~km}$ with 1300 hooks, about $40 \mathrm{~m}$ apart. Hooks were located at about $20 \mathrm{~m}$ depth. The ring-shaped hooks (model 9202, Mustad ${ }^{\mathrm{TM}}$, Lilleaker, Oslo area, Norway) measured $8 \mathrm{~cm}$ in total height and $2 \mathrm{~cm}$ in width.

The shape and size of the magnets were chosen to correspond to the size of the hook (Figure 2).

A positive and encouraging aspect of the experiment was that the fishermen were able themselves to place the magnets on the hooks without the assistance of the scientist (SBP), who just passed them the magnets stored in a polystyrene box. Inserting the hook within the magnet did not reduce the hectic speed of the immersion of the baited hook and the supporting line, lasting 7-8 h, by night, during a real fishing operation. The polarization of the magnets was randomly orientated so that the magnetic field $\mathrm{N}$ or $\mathrm{S}$ corresponded to the hook axis. Fishermen had no difficulty in attaching the magnets and removing them from the hook. The bait was located close to the magnet so that sharks would feel the magnetic field when trying to feed. The fishermen used only longfin inshore squid (Doryteuthis pealeii) (Lesueur, 1821) as bait. The longline carried the same number of hooks during the three days of the experiment. We divided the longline into 3 test zones with the same number of hooks (zone 1 at the beginning of the longline, zone 2 in the middle of the line and zone 3 at the end) and the rest of the longline was the zone 4 (Table 1; Figure 3). The reason for this partitioning is that zone 1 remained immersed for a longer time than zone 3 (approximately 7 hours) and this may influence the catch values. Within each test zone, we used 5 hooks with magnets of the first model, 11 hooks with magnets of the second model and 16 control hooks without magnets (Figure 3). The aim of this strategy was to observe whether there was any significant difference in the catch rate between test hooks and control hooks and between the two types of magnet within test zones. The rate of catch per unit of effort (CPUE) represents the relation between the number of individuals in catches and the number of hooks.

The three days were considered as replicates. We compared catch values for the 144 hooks with magnets from test zones 1 to 3 with144 control hooks under normal fishing conditions (i.e. without magnets)(Table 1). Inside the test zones, we tested the influence 
196

197

198

199

200

201

202

203

204

205

206

207

208

209

210

211

212

213

214

215

216

217

218

219

220

221

222

223

224

225

226

227

of different factors (size, sex, presence or absence of magnets and the models of magnet) on the CPUE values.

\section{Data treatment}

Data were analyzed with Statistica 9.1. Normality and homogeneity of variance were previously tested using Shapiro and Levene tests. One-way ANOVA was used in each zone and for all the tested zones together to test the differences in CPUE values between hooks with magnets and control hooks as well as between the two models of magnet.

\section{Results and discussion}

\section{Physical tests}

Figure 4 shows the measurement of the magnetic field in tesla (T) along the distance $\mathrm{X}$ in $\mathrm{cm}$ for a hook carrying respectively big magnets (big black circles) and small magnets (small grey circles) in a log-log scale. The lines correspond to the theoretical variation of the magnetic field as $\mathrm{X}^{-3}$. We note that despite the presence of the hook, for a distance more than $10 \mathrm{~cm}$, the magnetic field intensity varies like that of a dipole. At these distances, the intensity of the large magnets was twice as high as that of the smaller magnets.

The intensity of the magnetic field produced by the magnets has to be compared with the additional intensity of the magnetic field of the Earth (between $0.00002 \mathrm{~T}$ and $0.00007 \mathrm{~T}$, depending on the position on the Earth). From figure 4, we note that the intensity of the magnetic field from the magnets was the same intensity as that of the magnetic field of the Earth at a distance around 25 to $35 \mathrm{~cm}$ for small magnets, and 30 to $45 \mathrm{~cm}$ for big magnets.

An important aspect to be considered is that hooks equipped with both big and small magnets remained magnetized when removing the magnets and this phenomena is permanent (Figure 4). For example, a hook magnetized after contact with a big magnet at $6 \mathrm{~cm}$ distance induced the same magnetic field that a hook with a big magnet at $7 \mathrm{~cm}$ distance. Moreover, a hook alone which was never in contact with a magnet shows also a measurable magnetic field, even if it's lower than the magnetic field of hooks after contact with a magnet. For example at $6 \mathrm{~cm}$ distance from the hook which was never in 
contact with a magnet the magnetic field is equivalent to that of a hook with a big magnet model 1 measured at $8 \mathrm{~cm}$ distance.

\section{Experiments under real fishing conditions}

During the fishing campaign, 1076 blue shark Prionace glauca were caught by the longline vessel (Figure 5; Table 2). In addition to the blue sharks, one small swordfish Xiphias gladius, one albacore Thunnus alalunga (Bonnaterre, 1788), 3 sunfish Mola mola (Linnaeus, 1758), 6 pelagic stingray Pteroplatytrygon violacea (Bonaparte, 1832) and one common thresher shark Alopias vulpinus were caught.

The total length of the captured blue sharks ranged from 70 to $240 \mathrm{~cm}$, corresponding mainly to juvenile individuals (Table 2). For the blue shark, sexual maturity is reached at $180 \mathrm{~cm}$ in males and $200 \mathrm{~cm}$ in females (Moreno, 2004).

Sex ratio (\% of males) was $0.52-0.55$ in the tested zones 1 to 3 and 0.77 in the zone 4. The total length and sex of the caught individuals did not differ significantly according to whether they were caught with hooks equipped with magnets or not ( $p=0.062$, respectively $\mathrm{p}=0.892$ ).

The presence of the magnets had a significant effect on the catch rate per unit of effort (CPUE) only in the zones $2(\mathrm{~F}=10.48 ; \mathrm{p}=0.014)$ and $3(\mathrm{~F}=7.99 ; \mathrm{p}=0.026)$ with higher CPUE values for hooks equipped with magnets in both areas $(0.73$ in zone 2 and 0.75 in zone 3 for hooks with magnets compared to 0.52 and 0.38 respectively for hooks without magnets) (Table 1; Figure 6). These values were significantly higher only for the hooks equipped with the model 1 magnet (0.80) than for the control hooks in the zone $2(0.52)(\mathrm{F}=5.25 ; \mathrm{p}=0.048)$. In contrast, there were no significant differences in CPUE between the two magnet models 1 and 2, between model 2 magnet hooks and the control hooks in the zone 2, and between the two magnet models and the control hooks in the zones 1 and 3.

Globally for all the tested areas CPUE values for hooks with magnets are higher than those of hooks without magnets (mean 0.74 , SD 0.15 and respectively mean 0.47 , SD 0.17) $(\mathrm{F}=18.29, \mathrm{p}=0.000)$. These values are also higher than those of CPUE in the zone 4 (mean 0.25, SD 0.43). However as the number of hooks is much higher in the zone 4 (1204 hooks x 3 days) than in the tested zones (48 hooks x 3 days) this might influence the comparison between the mean CPUE values among these zones. 
260

261

262

263

264

265

266

267

268

269

270

271

272

273

274

275

276

277

278

279

280

281

282

283

284

285

286

287

288

289

290

291

It remains unclear whether it is the absolute strength of the magnetic field in the water, which at some level induces reaction behaviour of blue sharks, or whether it is the magnitude of the change in magnetism with distance that elicits the response. However, the presence of magnets near the hook did not provide the expected repellent effect. One of the two tested models of magnet even increased the catch rate. Magnets would therefore not appear to constitute an effective device to avoid by-catch for this species in real fishing conditions. Our results would appear to contradict these promising experimental previous results. However, several factors are to be considered. (i) Results from the literature are mainly based upon laboratory experiments, and/or in situ experiments more or less remote from the real conditions of a professional fishing fleet (Stoner and Kaimmer, 2008; Tallack and Mandelman, 2009; O'Connell et al., 2011a, 2014; Robbins et al., 2011). (ii) Clearly, the results from previous authors evidence the non-congruence of deterrent effects depending upon the species (Hutchinson et al., 2012); for example, these authors showed the ineffectiveness of EPM with blue shark and shortfin mako, although effective with another species (Annex 1). (iii) Our results, together with similar results from the literature (e.g. Hutchinson et al., 2012), concern juveniles. It is known that the electrosensory sensitivity, in many elasmobranchs, increases with growth (e.g. Fishelson and Baranes, 1999; Tricas and Sisneros, 2004).

(iv) The repellent devices used in the literature are rather disparate. Their characteristics and strength are often poorly described. In addition, the effectiveness of the magnet is influenced by the parallelism, or non-parallelism, of the axis of polarization with the axis of the hook (O'Connell et al., 2011a).

Most of the previously published papers on the deterrent effect on sharks tested the effects of electropositive metals (Annex 1), excepting Rigg et al., (2009). This is the first paper describing the magnetic effect on blue shark catch. Previous papers concerning the blue shark analyzed only the electropositive effects (Godin Cosandey et al., 2013; O'Connell et al., 2014d) (Annex 1). In our case, blue shark probably detects by odour at a large distance the presence of bait on the longlines. However at a short distance when swimming towards the bait it should feel the electric field induced by both the magnet and the electropositive metal. We probably have a cumulated effect of electric field induced the shark movement in the magnetic field and an electric field generated by the electropositive metal in contact with seawater that we cannot dissociate 
292

293

294

295

296

297

298

299

300

301

302

303

304

305

306

307

308

309

310

311

312

313

in field conditions. The measurements in laboratory concerned only magnetic field, but in perspective we will try to develop a protocol to measure the electric field too.

Our results, as well as others experiments in real fishing conditions did not reduce the by-catch of sharks (Godin Cosandey et al., 2013). Permanent magnet or electropositive metal is actually not proved yet as a solution to limit by-catch or to reduce negative impact of longline fisheries. As suggested by Jordan et al., (2013), we will have to explore new approaches to reduce the by-catch of sharks, as magnets seem to even have an attraction effect. Other management measures such as quotas or minimum catch length may be more appropriate for blue shark fishery.

\section{Acknowledgments}

We gratefully acknowledge the Captain and crews of the Pescalema based in Muxía (Galicia, Spain).This work was support by the Spanish Ministry of Agriculture, Food and Environment. The funding providers played no part in the study design, data collection, and analysis, decision to publish, or preparation to the manuscript. Thanks are also due to Michael Paul for improvement of the English. Finally, we acknowledge the two anonymous reviewers for valuable comments and suggestions.

\section{References}

Baum, J.K., Myers, R.A., 2004. Shifting baselines and the decline of pelagic sharks in the Gulf of Mexico. Ecol. Lett. 7, 135-145.

Brill, R., Bushnell, P., Smith, L., Speaks, C., Sundaram, R., Stroud, E., Wang, J., 2009. The repulsive and feeding-deterrent effects of electropositive metals on Carcharhinus plumbeus. Fish. Bull. 107(3), 298-307.

Buencuerpo, V., Ríos, S., Morón, J., 1998. Pelagic sharks associated with the swordfish Xiphias gladius fishery in the eastern north Atlantic Ocean and the Strait of Gibraltar. Fish. Bull. 96, 667-685.

Ferretti, F., Myers, R.A., Serena, F., Lotze, H.K., 2008. Loss of Large Predatory Sharks from the Mediterranean Sea. Conserv. Biol. 22(4), 952-964.

Ferretti, F., Worm, B., Britten, G.L., Heithaus, M.R, Lotze, H.K., 2010. Patterns and ecosystem consequences of shark declines in the ocean. Ecol. Lett. 13, 1055-1071. 
Fishelson, L., Baranes, A., 1999. Morphological and cytological ontogenesis of the ampullae of lorenzini and lateral line canals in the Oman shark, Iago omanensis Norman 1939 (Triakidae), from the Gulf of Aqaba, Red Sea. The Anatomical Record, 252(4), 532-545.

Godin Cosandey, A., Winner, T., Wang, J. H., Worm, B., 2013. No effect from rareearth metal deterrent on shark bycatch in a commercial pelagic longline trial. Fish. Res. 143, 131- 135 .

Hueter, R. E., Mann, D. A., Maruska, K. P., Sisneros, J. A., Demski, L. S., 2004. Sensory Biology of Elasmobranch. Chapter 12 in Biology of Sharks and their relatives. Ed. Carrier, J. C., Musick, J. A., Heithaus, M. R. CRC Press, 326358.Hutchinson, M., Wang J.H., Swimmer Y., Holland K., Kohin S., Dewar H., Wraith J., Vetter R., Heberer C., Martinez J., 2012. The effects of a lanthanide metal alloy on shark catch rates. Fish. Res. 131-133, 45- 51.

\section{IUCN 2013. IUCN Red List of Threatened Species. Version}

2013.2.<www.iucnredlist.org>. Downloaded on 02 June 2014.

Jordan, L.K., Mandelman, J.W., Kajiura, S.M., 2011. Behavioral responses to weak electric fields and a lanthanide metal in two shark species. J. Exp. Mar. Biol. Ecol. $409,345-350$.

Jordan, L.K., Mandelman, J.W., McComb, D.M., Fordham, S.V., Carlson, J.K., Werner, T.B., 2013. Linking sensory biology and fisheries bycatch reduction in elasmobranch fishes: a review with new directions for research. Conserv. Physiol. 409, 345-350.

Kalmijn, A.J., 1971. The electric sense of sharks and rays. J. Exp. Biol. 55, 371-383.

McKutcheon, S.M., Kajiura, S.M., 2013. Electrochemical properties of lanthanide metals in relation to theirapplication as shark repellents. Fish. Res. 147, 47- 54.

Moreno, J.A., 2004. Guía de los tiburones de aguas ibéricas, Atlántico nororiental y Mediterráneo. Barcelona: Omega publ. 315 p.

O’Connell, C.P., Abel, D.C., Rice, P.H., Stroud, E.M., Simuro, N.C., 2010. Response of the southern stingray (Dasyatis americana) and the nurse shark (Ginglymostoma cirratum) to permanent magnets. Mar. Fresh. Behav. Physiol. 43(1), 63-73.

O’Connell, C.P., Abel, D.C., Stroud, E.M., Rice, P.H., 2011a. Analysis of permanent magnets as elasmobranch bycatch reduction devices. Fish. Bull. 109, 394-401. 
O’Connell , C.P, Abel, D.C., Gruber, S.H., Stroud, E.M., Rice, P.H., 2011b. The response of juvenile lemon sharks, Negaprion brevirostris, to a magnetic barrier simulating a beach net. Ocean and Coastal Manag. 54, 225-230.

O'Connell, C.P., Stroud, E. M., and He, P., 2012. The Emerging Field of Electrosensory and Semiochemical Shark Repellents: Mechanisms of Detection, Overview of Past Studies, and Future Directions. Ocean and Coast. Manag. 97, 2-11.

O’Connell, C. P., Hyun, S-Y., Gruber, S. H., O’Connell, T. J., Johnson, G., Grudecki, K., He, P., 2014a. The use of permanent magnets to reduce elasmobranch encounter with a simulated beach net. 1. The bull shark (Carcharhinus leucas). Ocean and Coastal Manag. 97, 12-19.

O’Connell, C.P., Andreotti, S., Rutzen, M., Meÿer, M., He. P., 2014b. The use of permanent magnets to reduce elasmobranch encounter with a simulated beach net. 2. The great white shark (Carcharodon carcharias). Ocean and Coastal Manag. 97, 20-28.

O'Connell, C.P., Guttridge, T.L., Grube, S.H., Brooks, J., Finger, J.S., He, P., 2014c. Behavioral modification of visually deprived lemon sharks (Negaprion brevirostris) towards magnetic fields. J Exp Mar Biol Ecol. 453, 131-137.

O’Connell, C.P., He, P., Joyce, J., Stroud, E. M., Rice, P.H., 2014d. Effects of the SMART_(Selective Magnetic and Repellent-Treated) hook on spiny dogfish catch in a longline experiment in the Gulf of Maine. Ocean and Coastal Manag. $97,38-43$.

O’Connell, C.P., Hyun, S-Y., Gruber, S-H., He, P., 2015. Effects of barium-ferrite permanent magnets on great hammerhead shark Sphyrna mokarran behavior and implications for future conservation technologies. Endang. Species Res. 26, 243256.

Rice, P., 2008. A shocking discovery: how electropositive metals (EPMs) work and their effects on elasmobranchs. Workshop, 10-11 April 2008. US Department of Commerce, NOAA Technical Memorandum NOAA-TM-NMFS-PIFSC-16, 3640.

Rigg, D.P., Peverell, S.C., Hearndon ,M., Seymour, J.E., 2009. Do elasmobranch reactions to magnetic fields in water show promise for bycatch mitigation? Mar. Freshwater Res. 60(9), 942-948. 
Robbins, W.D., Peddemors, V.M., Kennelly, S.J., 2011. Assessment of permanent magnets and electropositive metals to reduce the line-based capture of Galapagos shark Carcharhinus galapagensis. Fish. Res. 109, 100-106.

Smith, K.T., 2013. Electrogenic metals for elasmobranch bycatch mitigation. Florida Atlantic University, Boca Raton, Florida. Master thesis. 35 pp.

Smith, L.E., O'Connell, C.P., 2012. The effects of neodymium-iron-boron permanent magnets on the behaviour of the small spotted catshark (Scyliorhinus canicula) and the thornback skate (Raja clavata). Ocean and Coastal Manag. 97, 44-49.

Stevens, J.D., Bonfil, R., Dulvy, N.K., Walker, P.A., 2000. The effects of fishing on sharks, rays and chimeras (chondrichthyans), and the implications for marine ecosystems. ICES J. Mar. Sci. 57, 476-494.

Stoner, A.W. and Kaimmer, S.M., 2008. Reducing elasmobranch bycatch: laboratory investigation of rare earth metal and magnetic deterrents with spiny dogfish and Pacific halibut. Fish. Res. 92, 162-168.

Tallack, S.M.L. and Mandelman, J.W., 2009. Do rare-earth metals deter spiny dogfish? A feasibility study on the use of electropositive "mischmetal" to reduce the bycatch of Squalus acanthias by hook gear in the Gulf of Maine. ICES J. Mar. Sci. $66, \$ 315-322$

Tricas, T.C., Sisneros, J.A., 2004. Ecological functions and adaptations of the elasmobranch electrosense. The sense of fish, Springer, Netherlands, 308-329

Wang, J.H., McNaughton,L., Swimmer,Y. A., 2008 shocking discovery: how electropositive metals (EPMs) work and their effects on elasmobranchs. Workshop, 10-11 April 2008. US Department of Commerce, NOAA Technical Memorandum NOAA-TM-NMFS-PIFSC-16, 36-40. 
Table 1. Comparison of mean values of CPUE (catch per unit of effort, where the unit of effort was the number of hooks) for blue shark (Prionace glauca) between longline zones during the test period (3 days). $\mathrm{No}=$ number. $\mathrm{SD}=\mathrm{Standard}$ Deviation.

\begin{tabular}{|l|c|c|c|c|c|c|c|c|c|}
\hline \multirow{2}{*}{$\begin{array}{l}\text { Blue shark } \\
\text { catch tests }\end{array}$} & \multicolumn{3}{|c|}{ Zone 1 } & \multicolumn{3}{c|}{ Zone 2 } & \multicolumn{3}{c|}{ Zone 3 } \\
\cline { 2 - 10 } & $\begin{array}{l}\text { No of } \\
\text { hooks }\end{array}$ & CPUE & SD & $\begin{array}{l}\text { No of } \\
\text { hooks }\end{array}$ & CPUE & SD & $\begin{array}{c}\text { No of } \\
\text { hooks }\end{array}$ & CPUE & SD \\
\hline $\begin{array}{l}\text { Magnet } \\
\text { model n } 1\end{array}$ & $3 \times 5$ & 0.87 & 0.35 & $3 * 5$ & 0.80 & 0.45 & $3 * 5$ & 0.80 & 0.41 \\
\hline $\begin{array}{l}\text { Magnet } \\
\text { model n } 2\end{array}$ & $3 \times 11$ & 0.64 & 0.49 & $3 * 11$ & 0.70 & 0.47 & $3 * 11$ & 0.70 & 0.47 \\
\hline $\begin{array}{l}\text { Hooks } \\
\text { without } \\
\text { magnets }\end{array}$ & $3 \times 16$ & 0.52 & 0.51 & $3 \times 16$ & 0.52 & 0.50 & $3 \times 16$ & 0.38 & 0.49 \\
\hline
\end{tabular}


Table 2. Total length $(\mathrm{TL})$ of captured blue sharks. $-=$ missing data, Min $=$ Minimum, Max $=$ Maximum, $\mathrm{SD}=$ standard deviation .

422

\begin{tabular}{|l|c|c|c|c|}
\hline Blue sharks catch & $\mathrm{n}$ & $\begin{array}{c}\text { Min. and Max. } \\
\text { TL }\end{array}$ & Mean length (SD) & $\begin{array}{c}\text { Sex ratio } \\
\text { (\% of males) }\end{array}$ \\
\hline Total caught individuals & 1076 & 70 to $240 \mathrm{~cm}$ & - & - \\
\hline $\begin{array}{l}\text { Individual caught by hooks } \\
\text { equipped with magnets inside the } \\
\text { zones 1, 2 and 3 }\end{array}$ & 94 & 100 to $200 \mathrm{~cm}$ & $109(18) \mathrm{cm}$ & $52 \%$ \\
\hline $\begin{array}{l}\text { Individual caught by control } \\
\text { hooks inside the zones 1, 2 and 3 }\end{array}$ & 75 & 100 to $200 \mathrm{~cm}$ & $112(15) \mathrm{cm}$ & $55 \%$ \\
\hline $\begin{array}{l}\text { Individual caught by hooks } \\
\text { without magnets in the zone 4 }\end{array}$ & 907 & 100 to $200 \mathrm{~cm}$ & - & $77 \%$ \\
\hline
\end{tabular}

423 
Table 3. References concerning tests of electropositive and magnetic effects on sharks in laboratory (Lab) and field.

426

\begin{tabular}{|c|c|c|c|c|}
\hline Species & $\begin{array}{c}\begin{array}{c}\text { Electromagnetic } \\
\text { dispositive }\end{array} \\
\end{array}$ & Study & $\begin{array}{c}\text { Detterent } \\
\text { effect }\end{array}$ & References \\
\hline Prionace glauca & NdFeB N35 - NdNi N35 & Field & no & This study \\
\hline Sphyrna mokarran & $\mathrm{BaFe} 12 \mathrm{O} 19$ & Field & yes & O'Connell et al., 2015 \\
\hline Carcharhinus leucas & $\mathrm{BaFe} 12 \mathrm{O} 19$ & $\mathrm{Lab}$ & yes & O'Connell et al., 2014a \\
\hline Negaprion brevirostris & $\mathrm{BaFe12O19}$ & $\mathrm{Lab}$ & yes & O'Connell et al., 2014c \\
\hline Scyliorhinus canicula & $\mathrm{Nd} 2 \mathrm{Fe} 14 \mathrm{~B}$ & $\mathrm{Lab}$ & yes & Smith and O'Connell, 2014 \\
\hline Raja clavata & $\mathrm{Nd} 2 \mathrm{Fe} 14 \mathrm{~B}$ & Lab & yes & Smith and O'Connell, 2014 \\
\hline Carcharodon carcharias & $\mathrm{BaFe} 12 \mathrm{O} 19$ & Field & yes & O'Connell et al., 2014b \\
\hline Squalus acanthias & Electropositive metal & Field & yes & O'Connell et al., 2014d \\
\hline Amblyraja radiata & Electropositive metal & Field & no & O'Connell et al., 2014d \\
\hline Dipturus laevis & Electropositive metal & Field & no & O'Connell et al., 2014d \\
\hline Prionace glauca & Electropositive metal & Field & no & O'Connell et al., 2014d \\
\hline Rhizoprionodon terraenovae & Neodymium $(\mathrm{Nd})$ metal & Field & partial & Smith, 2013 \\
\hline Carcharhinus limbatus & Neodymium $(\mathrm{Nd})$ metal & Field & no & Smith, 2013 \\
\hline Negaprion brevirostris & Neodymium $(\mathrm{Nd})$ metal & $\mathrm{Lab}$ & no & McCutcheon and Kajiura, 2013 \\
\hline Sphyrna tiburo - group & Neodymium $(\mathrm{Nd})$ metal & $\mathrm{Lab}$ & no & McCutcheon and Kajiura, 2013 \\
\hline Sphyrna tiburo - individual & Neodymium $(\mathrm{Nd})$ metal & $\mathrm{Lab}$ & no & McCutcheon and Kajiura, 2013 \\
\hline Prionace glauca & Electropositive metal & Field & no & Godin Cosandey et al., 2013 \\
\hline Isurus oxyrinchus & Electropositive metal & Field & no & Godin Cosandey et al., 2013 \\
\hline Lamna nasus & Electropositive metal & Field & no & Godin Cosandey et al., 2013 \\
\hline Sphyrna lewini & $\operatorname{PrNdA}$ & Field & yes & Hutchinson et al., 2012 \\
\hline Carcharhinus plumbeus & $\operatorname{PrNdA}$ & Field & no & Hutchinson et al., 2012 \\
\hline Prionace glauca & $\operatorname{PrNdA}$ & Field & no & Hutchinson et al., 2012 \\
\hline Isurus oxyrinchus & PrNdA & Field & no & Hutchinson et al., 2012 \\
\hline Rhizoprionodon terraenovae & $\mathrm{Nd} 2 \mathrm{Fe} 14 \mathrm{~B}$ & Field & yes & O'Connell et al., 2011a \\
\hline Carcharhinus limbatus & $\mathrm{Nd} 2 \mathrm{Fe} 14 \mathrm{~B}$ & Field & no & O'Connell et al., 2011a \\
\hline Carcharhinus limbatus & $\mathrm{BaFe} 12 \mathrm{O} 19$ & Field & yes & O'Connell et al., 2011a \\
\hline Carcharhinus plumbeus & $\mathrm{BaFe} 12 \mathrm{O} 19$ & Field & no & O'Connell et al., 2011a \\
\hline Negaprion brevirostris & $\mathrm{BaFe12O19}$ & Field & yes & O'Connell et al., 2011a \\
\hline Carcharhinus acronotus & $\mathrm{BaFe} 12 \mathrm{O} 19$ & Field & no & O'Connell et al., 2011a \\
\hline Rhizoprionodon terraenovae & $\mathrm{Nd} 2 \mathrm{Fe} 14 \mathrm{~B}$ & Field & yes & O'Connell et al., 2011a \\
\hline Mustelus canis & $\mathrm{Nd} 2 \mathrm{Fe} 14 \mathrm{~B}$ & Field & yes & O'Connell et al., 2011a \\
\hline Squalus acanthias & $\mathrm{Nd} 2 \mathrm{Fe} 14 \mathrm{~B}$ & Field & no & O'Connell et al., 2011a \\
\hline Dasyatis americana & $\mathrm{BaFe} 12 \mathrm{O} 19$ & Field & yes & O'Connell et al., 2011a \\
\hline Dasyatis americana & $\mathrm{Nd} 2 \mathrm{Fe} 14 \mathrm{~B}$ & Field & no & $\mathrm{O}^{\prime}$ Connell et al., 2011a \\
\hline Raja eglanteria & $\mathrm{Nd} 2 \mathrm{Fe} 14 \mathrm{~B}$ & Field & no & O'Connell et al., 2011a \\
\hline Carcharhinus plumbeus & $\mathrm{Nd} 2 \mathrm{Fe} 14 \mathrm{~B}$ & Field & no & O'Connell et al., 2011a \\
\hline Carcharhinus limbatus & $\mathrm{Nd} 2 \mathrm{Fe} 14 \mathrm{~B}$ & Field & yes & O'Connell et al., 2011a \\
\hline Negaprion brevirostris & $\mathrm{BaFe} 12 \mathrm{O} 19$ & $\mathrm{Lab}$ & yes & O'Connell et al., 2011b \\
\hline Mustelus canis - group & Neodymium (Nd) metal & $\mathrm{Lab}$ & no & Jordan et al., 2011 \\
\hline Mustelus canis - individual & Neodymium $(\mathrm{Nd})$ metal & Lab & yes & Jordan et al., 2011 \\
\hline Dasyatis Americana & $\mathrm{BaFe} 12 \mathrm{O} 19$ & $\mathrm{Lab}$ & yes & O'Connell et al., 2010 \\
\hline Ginglymostoma cirratum & $\mathrm{BaFe} 12 \mathrm{O} 19$ & $\mathrm{Lab}$ & yes & O'Connell et al., 2010 \\
\hline Carcharhinus plumbeus & Electropositive metal & $\mathrm{Lab}$ & yes & Brill et al., 2009 \\
\hline Squalus acanthias & Electropositive metal & $\mathrm{Lab}$ & partial & Tallack and Mandelman, 2009 \\
\hline Squalus acanthias & Electropositive metal & Field & partial & Tallack and Mandelman, 2009 \\
\hline Sphyrna lewini & Ferrite magnet & $\mathrm{Lab}$ & yes & Rigg et al., 2009 \\
\hline Carcharhinus tilstoni & Ferrite magnet & $\mathrm{Lab}$ & yes & Rigg et al., 2009 \\
\hline Carcharhinus amblyrhynchos & Ferrite magnet & $\mathrm{Lab}$ & yes & Rigg et al., 2009 \\
\hline Rhizoprionodon acutus & Ferrite magnet & Lab & yes & Rigg et al., 2009 \\
\hline Glyphis glyphis & Ferrite magnet & $\mathrm{Lab}$ & no & Rigg et al., 2009 \\
\hline Squalus acanthius & $\mathrm{Nd} 2 \mathrm{Fe} 14 \mathrm{~B}$ & $\mathrm{Lab}$ & no & Stoner and Kaimmer, 2008 \\
\hline Squalus acanthius & Electropositive metal & $\mathrm{Lab}$ & no & Stoner and Kaimmer, 2008 \\
\hline
\end{tabular}




\begin{tabular}{|c|c|c|c|c|}
\hline Squalus acanthias & Neodymium (Nd) metal & Lab & yes & Jordan et al., 2008 \\
\hline Mustelus canis & Neodymium (Nd) metal & Lab & yes & Jordan et al., 2008 \\
\hline Carcharhinus galapagensis & Electropositive metal & Field & yes & Wang et al., 2008 \\
\hline Carcharhinus plumbeus & Electropositive metal & Field & yes & Wang et al., 2008 \\
\hline Negaprion brevirostris & Electropositive metal & Field & yes & Rice, 2008 \\
\hline Carcharhinus galapagensis & Neodymium (Nd) metal & Field & no & Robbins et al., 2008 \\
\hline Carcharhinus galapagensis & PrNdA & Field & no & Robbins et al., 2008 \\
\hline
\end{tabular}

427

428 


\section{Figure legends}

Figure 1. Map of the marine area (northeastern Atlantic) and location of the fishing zone (black oval) where magnet experiments were conducted.

Figure 2. a. Position of the magnet model 2 with a hook under real fishing conditions. Photo: Sebastián Biton Porsmoguer. b. Position of magnet model 2 on a hook measured for magnetic field in laboratory. Photo: Christophe Almarcha.

Figure 3. Position of hooks with magnet models 1, 2 and control hooks in the testedzones 1, 2 and 3. The rest of the longline was the zone 4.

Figure 4. Measurement of the maximum magnetic field $\mathrm{B}$ in tesla $(\mathrm{T})$ along the distance $\mathrm{X}$ in $\mathrm{cm}$ for a hook filled with, respectively, big magnet for model 1 (big black circles), small magnet for model 2 (small grey circles), a hook alone after contact with big magnet model 1, a hook alone after contact with small magnet model 2 and a hook alone which was never in contact with a magnets (white circles), in a log-log scale.

Figure 5. A blue shark Prionace glauca caught by the longline vessel during the fishing campaign. Photo: Sebastián Biton Porsmoguer.

Figure 6. Comparison of the CPUE (catch per unit of effort) with mean values for blue shark (Prionace glauca) between the two model of magnets $(\mathrm{M} 1=$ model $1, \mathrm{M} 2=$ model 2) and the control hooks inside the tested zones. 
454

455

456

457

458

459

460

461

462

463

464

465

466

467

468

469

470

471

472

473

474

475

476

477

478

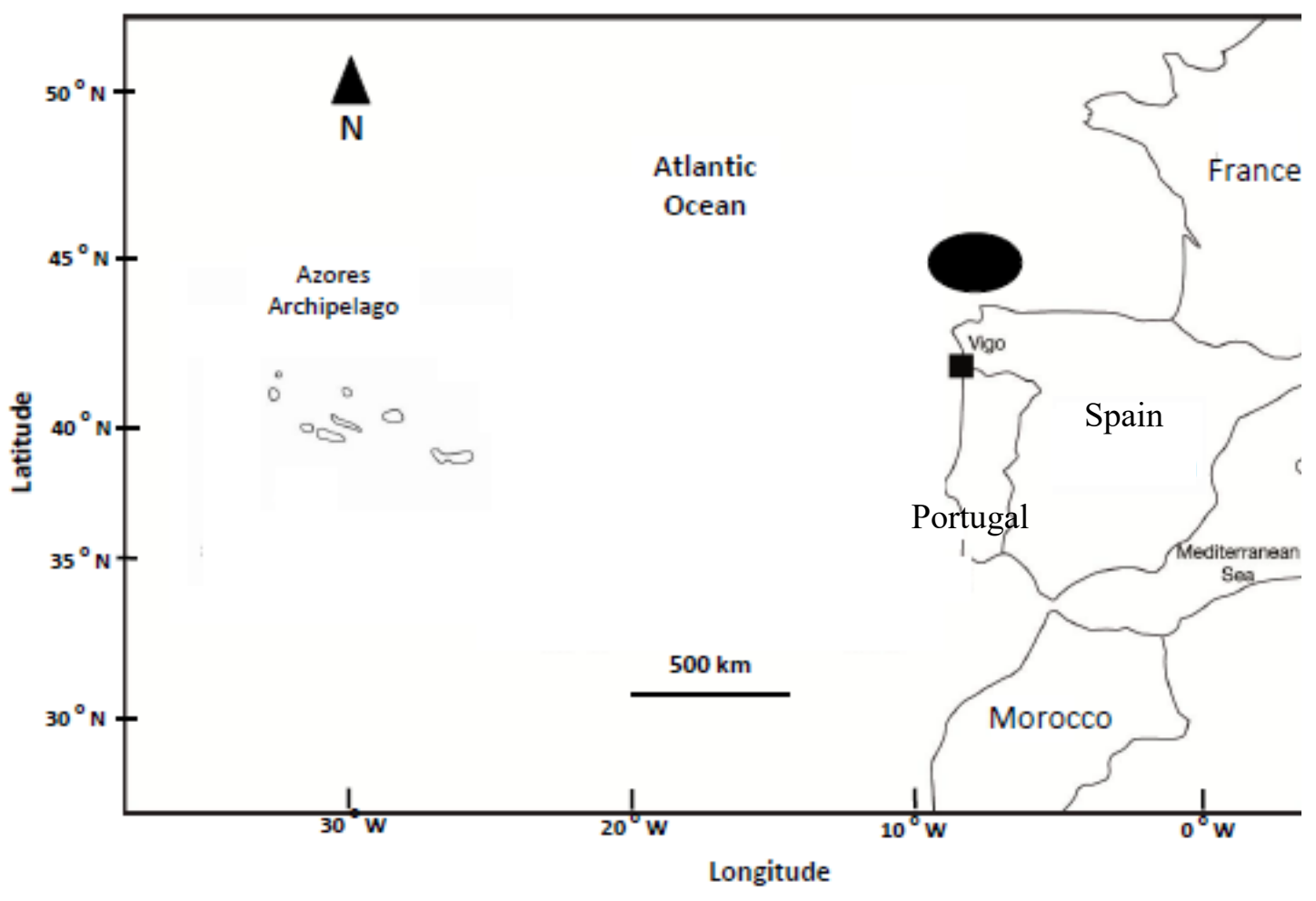

Figure 1. 
479

480

481

482

483

484

485

486

487

488

489

490

491

492

493
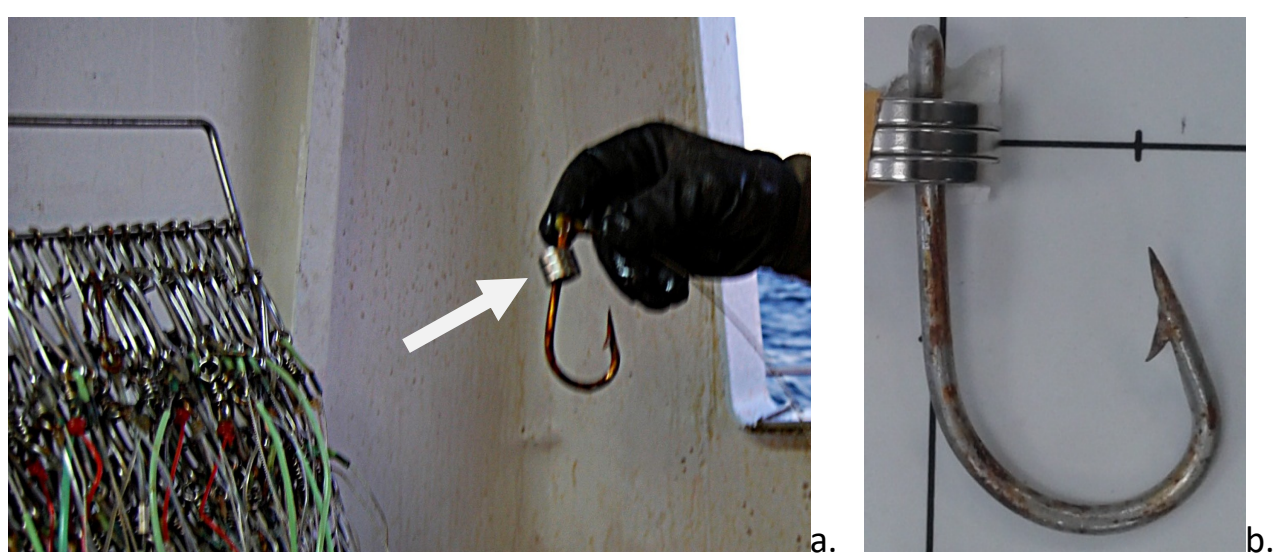

Figure 2. 
494

495

496

497

498

499

500

501

502

503

504

505

506

507

508

509

510

511

512

513

514

515

516

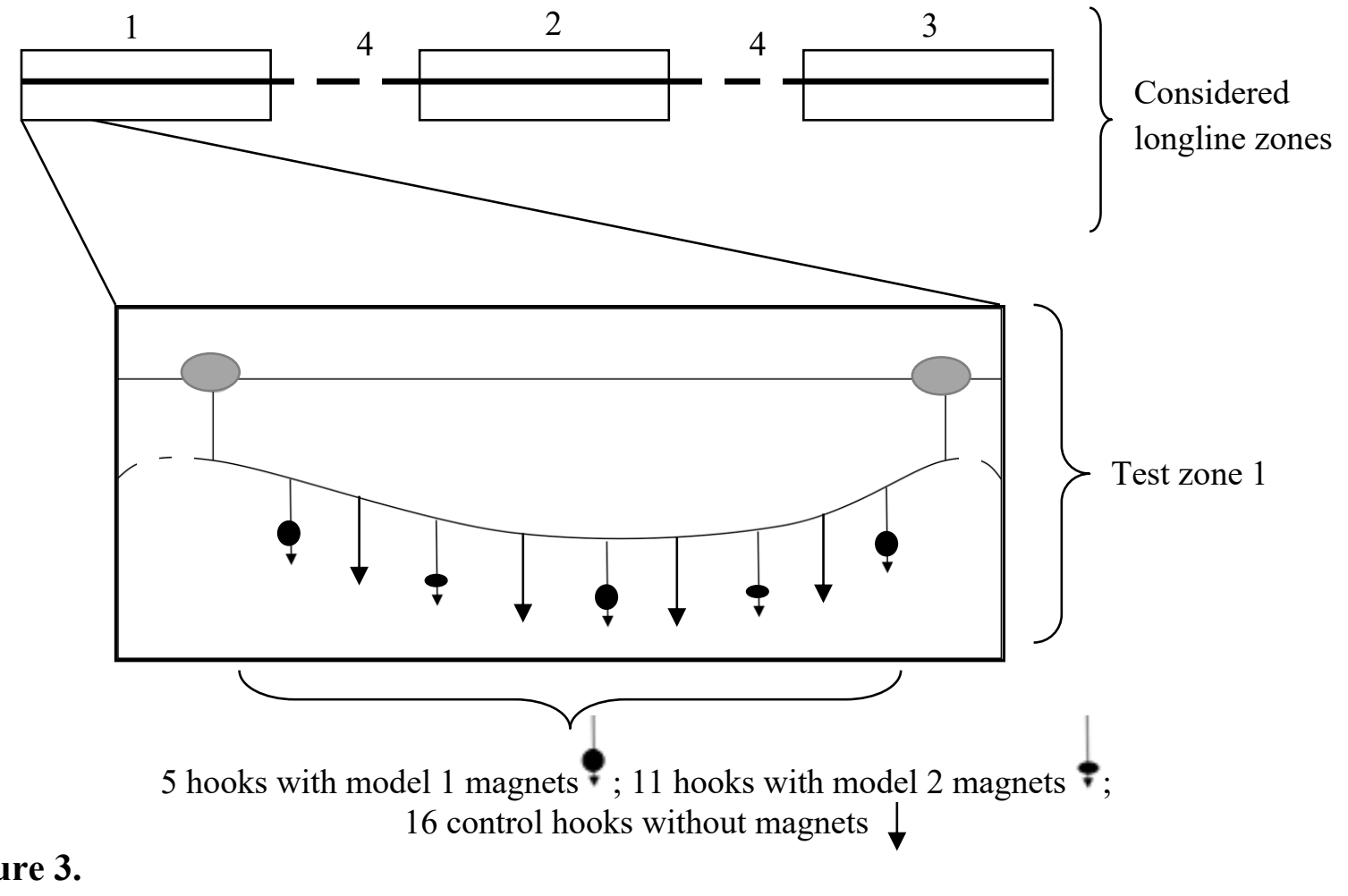

\section{Figure 3.}

16 control hooks without magnets 
517

$\mathrm{X}(\mathrm{cm})_{1}$

10

100

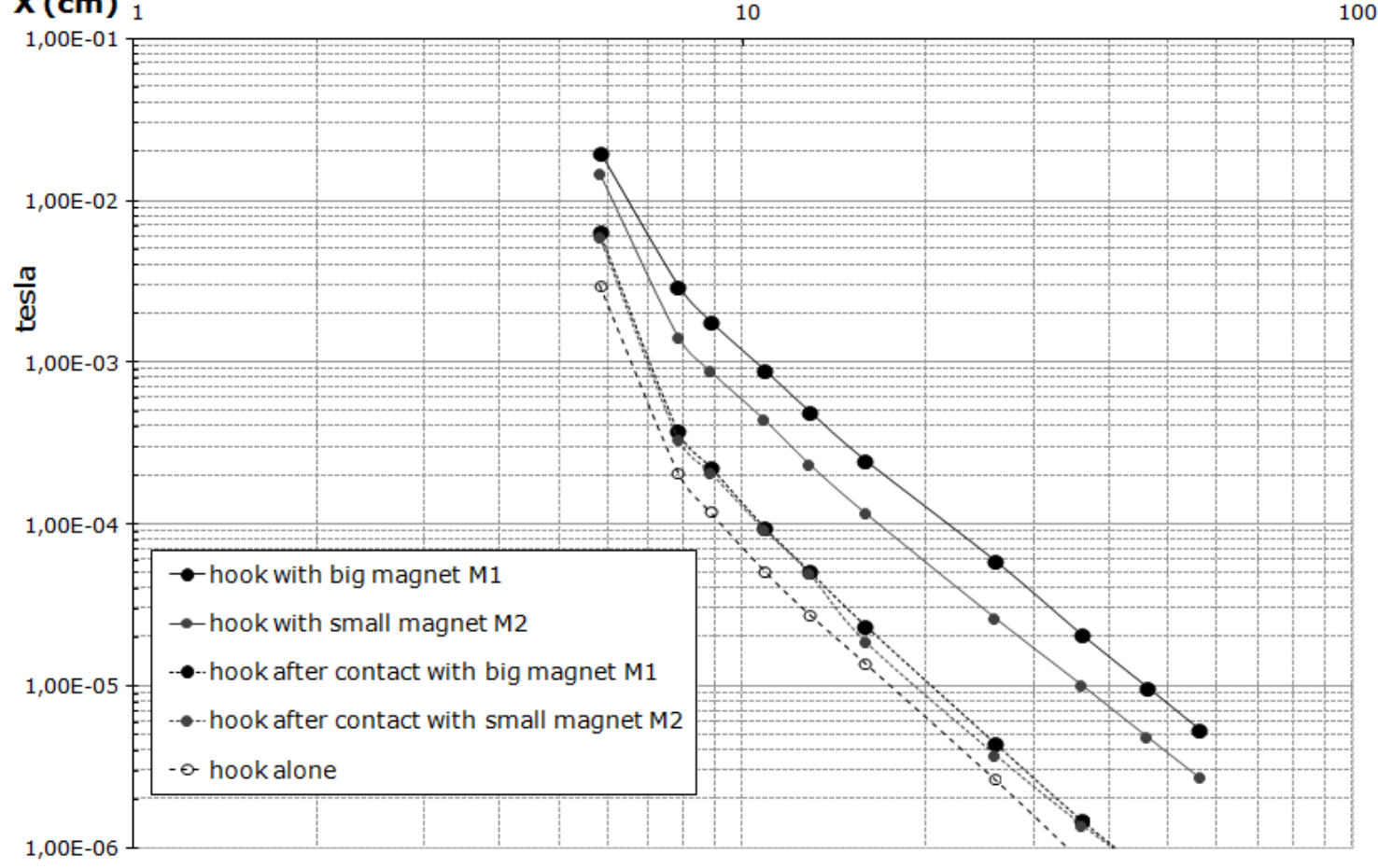

518

519

520

Figure 4.

521 


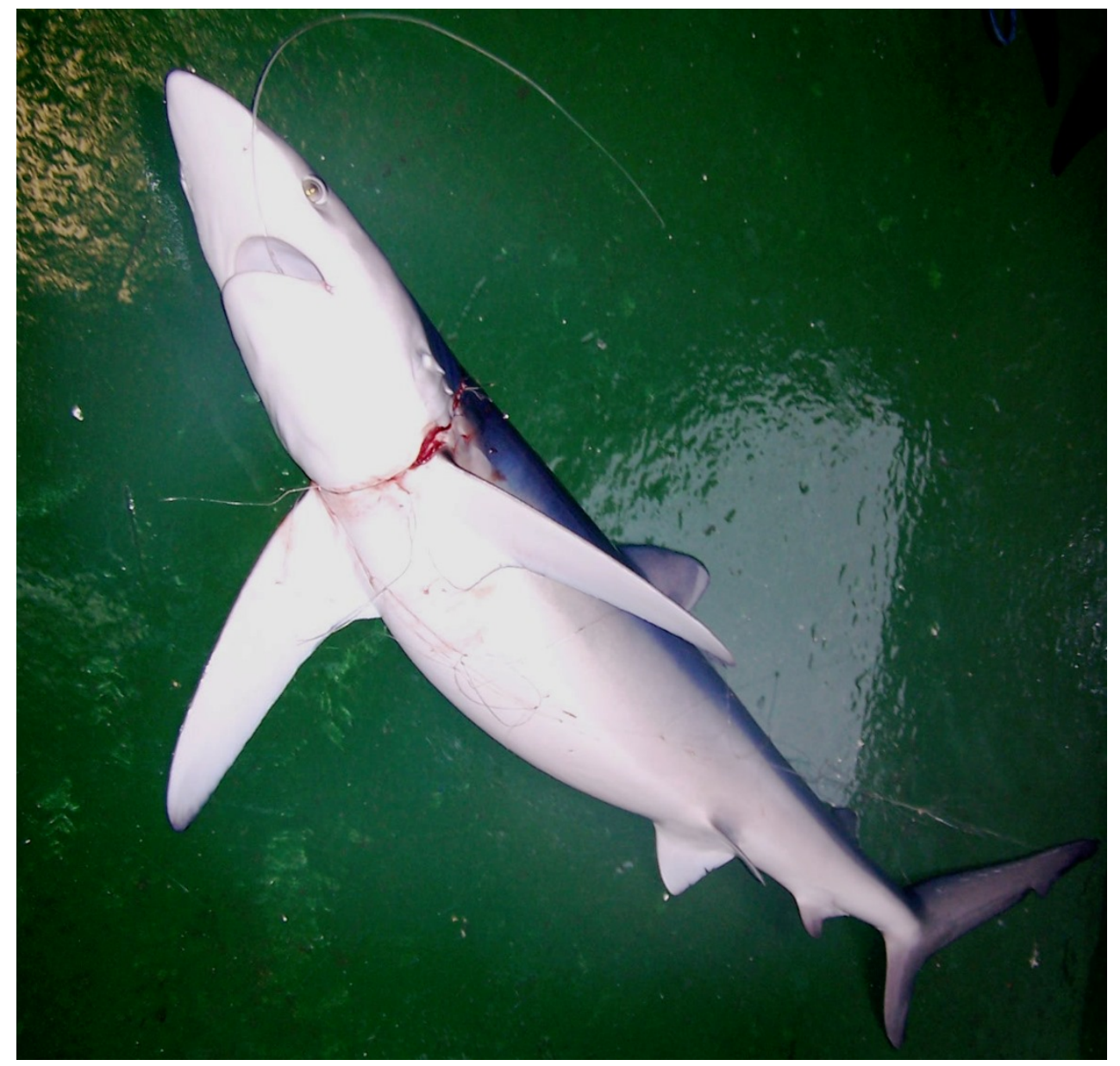

522

523

524 Figure 5.

525 


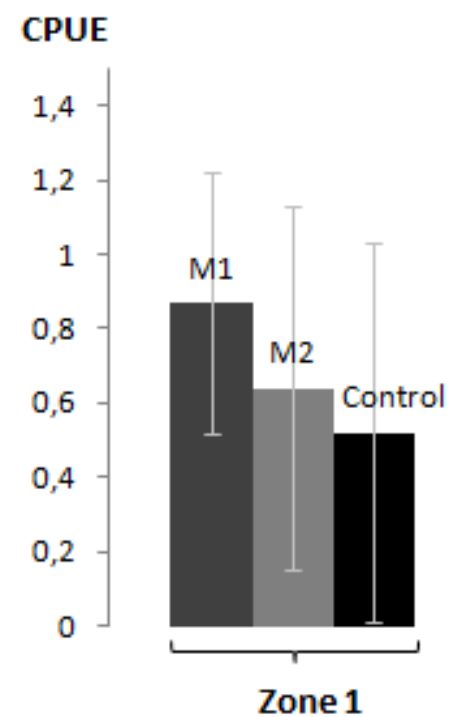

526

527

528

Figure 6.
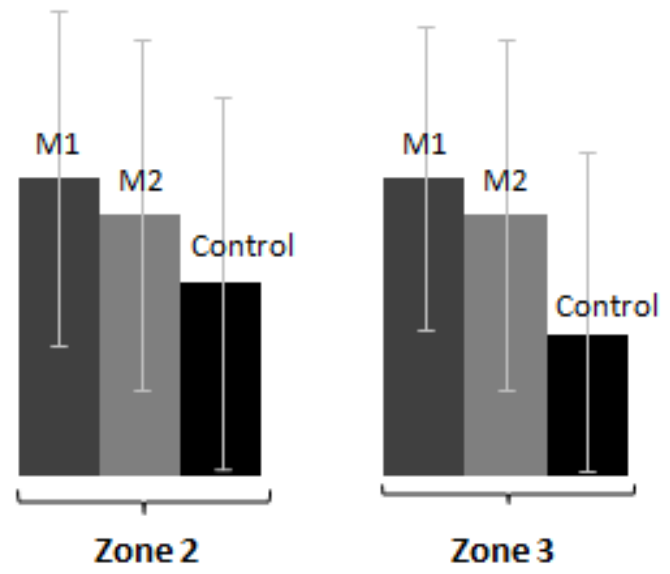